\title{
Contemporary Historiography on the Beginnings of Islam in North Africa
}

Anis Mkacher

UMR 8546 CNRS-ENS-EPHE (PSL)

anis.mkacher@gmail.com

\section{Mohamed Benabbès}

\section{Université de Tunis}

moh.benabbes@gmail.com - https://orcid.org/0000-0001-6960-7984

\section{Fecha recepción 25/02/2021 | Fecha aceptación 13/09/2021}

\section{Abstract}

The $7^{\text {th }}$ century CE was a turning point in the evolution of North Africa, with the Arab-Muslim conquest ushering in a period of decisive change. This study seeks to develop a grid for reading the contemporary historiography on this period. We begin by focusing on the origins of studies of the topic and then turn to a division between Western and Arab authors, in order to provide a sense of the geographical specificities of the extant scholarship. In doing so, we are able to see how the Arab conquest and the arri-

\section{Résumé}

Le VII siècle de l'ère chrétienne constitue un tournant décisif dans l'évolution du Nord de l'Afrique où la conquête arabo-musulmane a ouvert une période de mutation. Lobjet de cette étude est de proposer une grille de lecture de l'historiographie contemporaine réservée à cette période. En mettant l'accent, tout d'abord, sur les débuts des études sur la question, puis, selon une division entre auteurs occidentaux et auteurs arabes, pour bien voir les spécificités géographiques, nous avons essayé de voir com- 
Monográfico | Contemporary Historiography on the Beginnings of Islam in North Africa

val of Islam in the region have been represented, and then observe the gradual development of the scholarship on this period into a fully-fledged field of historical studies.

\section{Keywords}

Arab Conquest, Contemporary period, Historiography, Islam, North Africa ment les débuts de l'Islam et la conquête ont été représentés pour ensuite observer la constitution progressive de cette période en un champ d'études historiques à part entière.

\section{Mots-clés}

Afrique du Nord, Conquête arabe, Époque contemporaine, Historiographie, Islam 
The Arab conquest of the Maghreb and the place of Islam as the "new religion" of this region is an exceptionally rich historical topic that has attracted considerable scholarly interest. As a result, it is not possible to provide an exhaustive bibliography. In what follows, we will content ourselves with drawing up a chronological table of the major studies that have been carried out on the subject. This approach will allow us to identify who the specialists are on particular questions and who participated in the development of the research, in particular by drawing on sources originally written in Arabic ${ }^{1}$.

While this initial direct approach to the sources has been vital for the evolution of scholarship in this subject area, in recent years many sources relating to the African region have also become accessible to non-Arabists in translation. Indeed, Arabic editions are now often accompanied by translations published in various European languages, a development that has facilitated the exploration of these sources by Western historians.

\section{Western Historiography}

\subsection{Translations of Arabic Chronicles and the First General Studies}

It is impossible to speak of $19^{\text {th }}$-century scholarship on the Maghreb without mentioning the role of the philologist and Arabist, William Mac Guckin, Baron of Slane (1801-1878). While no expert on historical matters, the Baron of Slane nevertheless contributed a great deal to the field of research related to the conquest of the Maghreb. Indeed, it is thanks to his numerous translations of and rich commentaries on the accounts of Ibn 'Abd Al-Hakam, Nuwayrī, and Ibn Haldūn that a new perspective was provided to the specialists working on this topic².

1. Studies of the question prior to the modern period can be found in: L.-J. De Guignes, Histoire générale des Huns, Paris, 1756; Ch. Lebeau, Histoire du Bas-Empire, Paris, 1757 (a second edition annotated by Vivien de Saint-Martin was published in 1825); S. Ocley, The History of the Saracens, London, 1757; D.-D. Cardonne, Histoire de l'Afrique et de l'Espagne sous la domination des Arabes, Paris, 1765; E. Gibbon, The History of the Decline and Fall of the Roman Empire, London, 1776-1788; J.-A. Conde, Historia de la dominación de los árabes en España, sacada de varios manuscritos y memorias arábigas, 3 vols., Madrid, 1820-1821.

2. W. Mac Guckin, Histoire des Berbères et des dynasties musulmanes de l'Afrique septentrionale, 4 vols., Paris, 1852-1856; W. Mac Guckin, Description de l'Afrique septentrionale par El-Bekri, Paris, 1859; W. Mac 
For example, Henri Fournel (1799-1876) was able to write a series of pioneering studies by drawing on the Baron's translations. This mining engineer ${ }^{3}$ and historian treated the issue of the conquest most directly in his Étude sur la conquête de l'Afrique par les Arabes, published in $1857^{4}$, and Les Berbères. Étude sur la conquête de l'Afrique par les Arabes d'après les textes arabes imprimés ${ }^{5}$, published in 1875-1881 (volume 2 of which is edited by Louis-Olivier Harty de Pierrebourg in collaboration with Gustave Dugat). In these two monographs, Fournel seeks to prove that, despite being conquered by the Arabs and subjected to various oriental dynasties, the Maghreb had remained essentially Berber and that the departure of the Fatimids for Egypt finalised the failure of the conquerors and returned the country to its own control. Despite its controversial conclusions, Fournel's work was a great success and wielded considerable influence on later scholars, as can be seen in the similar conclusions found in the Histoire de l'établissement des Arabes dans l'Afrique septentrionale by French historian and politician Jean Ernest Mercier (1840-1907) 6 .

Another French author, the jurist and professor of Constitutional History, Maurice Caudel (1871-1950), wrote a text on the first Arab conquests entitled Les premières invasions arabes en Afrique $d u$ Nord, dealing with the period between 651 and $718 \mathrm{CE}^{7}$ (641-697 CE in a second version of the same work, published the year after). The author explains this thematic revival by declaring that "the Arab invasions in North Africa have already been studied more than once. I picked up the topic for two reasons. I could draw on two new sources of fairly serious interest for shedding light on the question. It seemed to me, moreover, that my predecessors had not employed the most suitable method for elucidating such an obscure question"s. The two sources to which the author refers here are $M a^{\prime} \bar{a}$ lim al-imān fì $M a^{\prime}$ rifat Ahl al-Kayrawān by Al-Dabbāg (d. in 1297), revised and annotated by Ibn Nāḡì (15 ${ }^{\text {th }}$ cent.), and Kitāb Riyāẹ Al-Nufūs by Al-Mālikī (d. after 1057).

It is worth noting, however, that Caudel's work was not unanimously appreciated by his colleagues, possibly because of his criticism of his predecessors. Moreover, many of his fellow

Guckin, "Ibn Hawkal, Kitâb al-Masâlik wa-l Mamâlik", Journal Asiatique, 13, 1842, 160-196 and 209-258.

3. Cf. H. Fournel, Rapport sur les mines de plomb argentifère du cap de Guerri (vallée d'Aran), Catalogne, concédées par le gouvernement espagnol à Hyppolyte Carvallo, Bordeaux, 1873.

4. H. Fournel, Étude sur la conquête de l'Afrique par les Arabes, et recherches sur les tribus berbères qui ont occupé le Maghreb central, Paris, 1857.

5. H. Fournel, Les Berbers. Étude sur la conquête de l'Afrique par les Arabes, d'après les textes arabes imprimés, 2 vols., Paris, 1875-1881.

6. J.E. Mercier, Histoire de l'établissement des Arabes dans l'Afrique septentrionale selon les documents fournis par les auteurs arabes et notamment par l'Histoire des Berbères d'Ibn Khaldoun, Constantine, 1875. See also J.E. Mercier, Comment l'Afrique septentrionale a été arabisée. Extrait résumé de l'histoire de l'établissement des Arabes dans l'Afrique septentrionale, Constantine, 1874; J.E. Mercier, Histoire de l'Afrique septentrionale (Berbérie) depuis les temps les plus reculés jusqu’à la conquête française (1830), Paris, 1888-1891.

7. M. Caudel, "Les premières invasions arabes dans l'Afrique du Nord (21-100 H. - 651-718 J.-C.)", Journal Asiatique, 1, 1899, 102-155, 189-237, 385-422.

8. M. Caudel, Les premières invasions arabes dans l'Afrique du Nord, Paris, 1900, I-II. 
historians considered the Arab conquest to be an episode that was of only limited interest in the history of the region, which had recently come under French domination. The markedly different opinion of Stéphane Gsell (1864-1932), a specialist on ancient Africa, provides a perfect example of such views and reflects well the ideological opposition to Caudel's treatment of the history of North Africa. Gsell writes,

"Je ne mentionne ici que pour mémoire un travail de M. Caudel, en cours de publication dans le Journal Asiatique), sous ce titre : Les premières invasions arabes dans l'Afrique du Nord (651718 J. C.). Au bout de près de 180 pages, M. Caudel n’a pas encore entamé son sujet. Il s'attarde à des généralisations fausses ou très discutables sur la psychologie et les mœurs des indigènes $\mathrm{du}$ Maghreb et des habitants de l'Arabie. Tout cela est écrit dans un style singulièrement prétentieux et déclamatoire. Il est fâcheux que la Société asiatique encombre sa revue de telles pauvretés"9.

Before closing this overview of early studies of the rise of Islam in the Maghreb, the contribution of Charles Diehl (1859-1944) must first be considered. This former member of the French Schools of Rome and Athens was an important authority on Byzantine Africa. His most important work, for which he received an award from the Academy of Inscriptions and Belles-Lettres, is Afrique byzantine. Histoire de la domination byzantine en Afrique (533709) ${ }^{10}$. This work, which discusses in detail the Arab conquest of the region and the fall of Byzantine domination from 641 to 709, remains a classic text even now for any historian interested in the Byzantine settlements in the region. Diehl understands the Arab arrival as accelerating the loss of Byzantine Africa, putting an end to any attempt to retaliate and regain the former position there. In pursuing this topic, Diehl relied on the previous work carried out by Arabists like Fournel and Mercier, but he moved the subject forward by integrating this with information drawn from Greco-Latin authors ${ }^{11}$.

\subsection{The French Orientalist Medievalists}

A critical turning point in the study of the conquest of the Maghreb came with the contributions made by a number of distinguished French specialists working on the Islamic Medieval period. The first of these was Albert Gateau's (1902-1949) edition of Ibn 'Abd Al-Hakam's

9. St. Gsell, "Chronique archéologique africaine", Mélanges d'Archéologie et d'Histoire - Antiquité, 20, 1900, 79-146 (101): "I only mention here for the record a work by M. Caudel, currently being published in the Asian Journal, under this title: The first Arab invasions in North Africa (651-718 J. C.). After nearly 180 pages, Mr. Caudel has not yet begun his subject. He dwells on false or highly questionable generalizations about the psychology and mores of the natives of the Maghreb and the inhabitants of Arabia. All of this is written in a singularly pretentious and declamatory style. It is unfortunate that the Asian Society encumbers its review with such poor texts".

10. Ch. Diehl, L'Afrique byzantine. Histoire de la domination byzantine en Afrique (533-709), Paris, 1896.

11. Ch. Diehl, L'Afrique byzantine..., op. cit., n. 10, 584. 
text, which is concerned with the Muslim conquest of Egypt and the Maghreb ${ }^{12}$. Gateau's edition was a rarity in providing a European translation of a medieval Arabic source in parallel with the original text. It also came with a very interesting critical apparatus that identifies a number of particularly useful comparisons with other Arab accounts of the conquests of North Africa and Spain.

The second contribution was made by Robert Brunschvig (1901-1990). In a paper on Ibn 'Abd Al-Hakam and the Arab conquest of North Africa, Brunschvig showed, for the first time, the importance of legal or legislative considerations in the formation of early accounts of the conquest, particularly among Faqih historians such as Ibn 'Abd Al-Hakam. This scepticism about the historicity of the accounts of the conquest is also clear in his study of Muslim expansion in the Libyan Fezzan ${ }^{13}$.

Georges Marçais (1876-1962), who was especially well known for his work on Islamic archeology $y^{14}$, was one of the first historians to occupy the chair of Muslim Archaeology at the Faculty of Algiers. Marçais wrote an extensive section on the Arab conquest of the Maghreb in his La Berbérie musulmane et l'Orient au Moyen Âge ${ }^{15}$. He then went on to produce a study of the 'Uqba, Abū-l-Muhāğir, and Kusayla ${ }^{16}$.

Évariste Lévi-Provençal (1894-1956) also made a number of notable contributions to the historical research on the Maghreb. In particular, his 1954 discovery of a new narrative text concerning the North African conquest ${ }^{17}$ has enabled a significant advance in the treatment of the topic. Hady Roger Idris (1912-1978) has also made important contributions, both through his translation of Al-Mālikī's account of the conquest of Ifrìqiya ${ }^{18}$ and his comparative analysis of this "Kairouanais" author alongside another Maghrebian author, Ibn 'Id̄ārī (14 ${ }^{\text {th }}$ cent.)

An unintended, but not unimportant, result of the work carried out by these eminent French orientalists is that research into the beginnings of Islam in the Maghreb has tended to be anchored in the field of Medieval studies. Consequently, the question has received little

12. A. Gateau, Ibn 'Abd al-H'akam. Conquête de l'Afrique du Nord et de l'Espagne (Futûh' Ifrîqiya wa'lAndalus). Texte arabe et traduction française avec une introduction et des notes, Alger, 1942.

13. R. Brunschvig, "Un texte arabe du IX siècle intéressant le Fezzan”, Revue Africaine, 89, 1945, 21-25.

14. G. Marçais, L’architecture musulmane d'Occident. Tunisie, Algérie, Maroc, Espagne et Sicile, Paris, 1954.

15. G. Marçais, La Berbérie musulmane et l'Orient au Moyen Age, Paris, 1946. Cf. also G. Marçais, Les Arabes en Berbérie du XIe au XIV siècle, Paris, 1913.

16. G. Marçais, "Sidi 'Uqba, Abû-1-Muhajir et Kusayla", Cahiers de Tunisie, 1, 1953, 11-17.

17. É. Lévi-Provençal, "Ibn 'Abd al-Halim, Fath al-Arab li-l-Maghreb", Revista del Instituto de Estudios Islámicos en Madrid, 2, 1954, 193-224; É. Lévi-Provençal, "Un nouveau récit de la conquête de l’Afrique du Nord", Arabica, 1, 1954, 17-52.

18. H.-R. Idris, "Examen critique des récits d'al-Mâliki et d'Ibn 'Idâri sur la conquête de l' Ifriqiya”, Arabica, 11, 1964, 5-18; H.-R. Idris, "Le récit d'al-Mâliki sur la conquête de l'Ifriqiya”, Revue des Études Islamiques, 37, 1969, 117-149. 
attention from specialists focusing on Late Antiquity, a term that did not appear in French or English until the late 1960s.

\subsection{Other Western Research during the 20th Century}

The richness of the historiography on the Arab conquest of the Maghreb derives to a not inconsiderable degree from the interest shown in the subject by historians from a wide range of European countries. In Italy, the Arabist Michel Amari (1806-1889) clearly showed the importance of Arab stories for illuminating the history of Sicily from the Arab conquest to the establishment of Norman rule. Indeed, the period of Italian colonial rule over Libya was one of the most fertile for the generation of advances in the scholarly understanding of Libyan history and its relation to the histories of its geographical neighbours ${ }^{19}$.

In the case of Spain, studies of the conquest of North Africa have often focused on problems with the sources ${ }^{20}$, in addition to the importance of the Maghreb region during the conquest of the peninsula and its later evolution in relation to Arab rule in Spain.

Anglo-Saxon research has benefited from a number of notable trends: the discussion in the 1970s of the authenticity of the Islamic historical sources ${ }^{21}$; the extension to the $8^{\text {th }}$ century of the concept of Late Antiquity, under the auspices of the historian Peter Brown, which brought the conquest into focus for classicists and ancient historians working on this period ${ }^{22}$; and an interest in the Byzantine influence on the $7^{\text {th }}$ century Mediterranean. With regard to the first trend, the first works addressing the question of authenticity also provide syntheses on the early Arab conquests more generally ${ }^{23}$, although they were not, initially at least, concerned specifically with the movement into the Maghreb. However, as time passed, the focus of these discussions began to shift towards North Africa. We can cite as examples Michael Brett's chapter on the topic ${ }^{24}$ and the meticulous study of the

19. See E. Rossi, Storia di Tripoli e della Tripolitania dalla conquista araba al 1911, Roma, 1968 (esp. ch. 3, "La conquista musulmana della Tripolitania. I primi governatori musulmani della Ifriqiyah e di Tripoli", pp. 3-105); E. Rossi, "Le epigrafi musulmane del Museo di Tripoli”, Libia, 1, 1953, 103-107; A. Malvezzi, L'Italia e l'Islam in Libia, Milano, 1913.

20. M.-E. Moreno, "Las fuentes árabes sobre la conquista de Al-Ándalus: una nueva interpretación”, $R e$ vista Española de Historia, 59, 1999, 389-432; A.-G. Sanjuán, "Las causas de la conquista islámica de la Península Ibérica según las crónicas medievales”, Miscelánea de Estudios Árabes y Hebraicos. Sección ArabeIslam, 53, 2004, 101-127.

21. J. Wansbrough, "On Recomposing the Islamic History of North Africa”, Journal of the Royal Asiatic Society, 2, 1969, 161-170.

22. P. Brown, The World of Late Antiquity AD 150-750, New York, 1971.

23. F.M. Donner, The Early Islamic Conquests, Princeton, 1981.

24. See M. Brett, “The Arab Conquest and the Rise of Islam in North Africa”, in J.D. Fage (ed.), The Cambridge History of Africa, vol. 2 (500 B.C. - A.D. 1050), Cambridge and New York, 1979, 490-555. Cf. also A.D. Taha, The Muslim Conquest and Settlement of North Africa and Spain, London, 1989, even if this latter text is more interested in Spain. 
beginning of the Muslim occupation of Libya written in 1967 by Richard G. Goodchild, an archaeologist and historian of Late Antiquity ${ }^{25}$. In the latter work, the author draws a comparison between the Arab traditions on the Muslim conquest of Tripolitania and Cyrenaica, on the one hand, and the narratives of Christian writers, such as John of Nikiu and Severus of El Ashmunein, on the other.

Byzantine scholarship has served to confirm the conclusions of the earlier studies regarding the importance of the Arab conquest during the $7^{\text {th }}$ century. One such example can be found in the monumental works of Andreas N. Stratos (1905-1981) ${ }^{26}$. Meanwhile, Denys Pringle, in a study of the defensive works of the Byzantines in North Africa, provides a lucid overview of the events of the Arab conquest ${ }^{27}$, as does Vassilios Christides, who studied the presence of Byzantium in Libya ${ }^{28}$. One of the merits of Christides' book in particular is that it emphasises the role played by Byzantine maritime superiority in slowing down the first Arab invasions in North Africa.

\section{Contemporary Arab Historians and the Beginning of Islam in the Maghreb}

So far, we have focused on the work and views of Western writers, but to these we will now add examples drawn from contemporary Arab historians. A major challenge faced when considering these scholars, just as is the case for their Western counterparts, is the wide range of different perspectives from which the topic is approached. While a classical methodology, combining historical developments and geographical origin, has been preferred in the first section of this chapter when dealing with the Western scholarship, such an approach is more problematic when considering Arab or Arabic-speaking historians. Taking account of the geographical origins of the writers in question quickly draws our attention to the important fact that, with the exception of a small number of Egyptian scholars, the other writings derive almost exclusively from Maghrebi authors who are interested in "reappropriating" their local history. These attempts lead to highly divergent results.

25. R.G. Goodchild, "Byzantines, Berbers and Arabs in $7^{\text {th }}$ Century Libya”, Antiquity, 41, 1967, 15-124.

26. A.N. Stratos, Byzantium in the Seventh Century, 6 vols., Amsterdam, 1968-1983, previously published in Greek (Athens, 1965-1977).

27. D. Pringle, Defence of Byzantine Africa, from Justinian to the Arab Conquest. An Account of the Military History and Archaeology of the African Provinces in the Sixth and Seventh Centuries, 2 vols., Oxford, 1981, 43-50.

28. V. Christides, Byzantine Libya and the March of the Arabs towards the West of North Africa, BAR International Series 851, Oxford, 2000. 


\subsection{Egyptian Historians}

The study of the Arab conquest of Libya as described in Arab narratives - some of which have been published while others are still only available in manuscript form - has its origins in Egypt. One of the earliest $20^{\text {th }}$-century works we have identified clearly supports the hypothesis that Egypt was of central importance for the history of Libya. The book is entitled Tärīh 'Amr ibn al-' $\bar{A} s^{29}$ (History of 'Amr ibn al-' $\bar{A} s$ ), submitted by Hasan Ibrāhīm Ḥasan (1892-1968) in 1921 for a doctorate at the Egyptian University and then published in $1926^{30}$. In this "biography" of a famous conqueror, the writer focuses on the actions that took place in Libyan lands, while emphasizing the role of Egypt in the successful completion of the conquest ${ }^{31}$. The same scholar later broadened his focus to encompass the whole of the Islamic world ${ }^{32}$,


wa-al-iğtimā‘ (Political, Religious, Cultural and Social History of Islam).

In 1947, Husayn Mu'nis (1911-1996) provided additional details on the history of the conquest of the Maghreb with the publication of a compilation of sources ${ }^{33}$. A number of other Egyptian historians - for example, al-Sayyid 'Abd al-'Azīz (1928-2003) in 1960², 'Abd al-Ḥamīd Sa'ad Zag̣lūl (1934-2005) in 1964³, and Aḥmad Muhntār al-'Abbādī (1922-2016) in $1974^{36}$ - continued to elaborate the story of the conquest of the region over the following thirty years. In each of these studies, the structure of the work is very similar: the author lays out a general history of the Islamic Maghreb, organized around chronology, names, and places.

\subsection{Libyan Historians}

In the newly independent Libya of the post-war years, historians, writing almost exclusively in Arabic, sought at first to rewrite the history of the country in a spirit of decolonization. For several years, they completely turned away from pre-colonial history to focus on the history of the nation's liberation and independence. However, in developing a new post- and anti-colonial identity, that is, an anti-Western identity, Islam came to be seen as the funda-

29. H.-I Hasan, Tärīh 'Amr ibn al-'Ās, Cairo, 1926 (we used the 1996 edition in Arabic).

30. H..-I Hasan, Tārīh 'Amr ibn al- 'Ās, op. cit., n. 29, 13-18.

31. H..-I Hasan, Tärīh 'Amr ibn al- 'Ās, op. cit., n. 29, 185-186.

32. H..-I Hasan, Tārīh al-Islām al-siyāsī wa-al-dīnī wa-al-țaqāfì wa-al-iğtimā'ì, 3 vols., Cairo, 1948-1949 (in

Arabic). For all military operations under the Ummyads, including in the Maghreb, see 226-252.

33. H. Mu'nis, Fath al-'arab lil-maghrib, Cairo, 1947, 50-71; H. Mu'nis, "La conquête de l'Afrique du Nord et la résistance berbère”, in M. El Fasi and I. Hrbek (eds.), Histoire générale de l'Afrique, vol. 3. L'Afrique du $V I I^{e}$ au XI siècle, Paris, 1990, 251-272.

34. 'A.al-Sayyid, Tārīh al-Mag̀rib Fi al-'Asr al-Wasit, Alexandria, 1960, 55-66 (in Arabic).

35. 'A. Sa'ad Zag̀lūl, Tārīh al-Mag̀rib al-'Arabī, Cairo, 1964, 130-142. This is also the case of 'U. Farrūhn, al'Arab wa-al-islām fì l-ḥawḍ al-ġarbì min al-Bahr al-abyad-al-mutawassiț, Beyrouth, 1959, 50-56 (in Arabic).

36. A.-M. al-'Abbādī, Dirāsāt fì tārīh al-Mag̀rib wa-al-Andalus, Alexandria, 1974, 35-36 (in Arabic). 
mental element ${ }^{37}$. Consequently, the Islamic conquest of the region became a medium for the crystallization and elevation of this newly discovered identity. Two historians in particular are often cited in connection with this development: al-Ṭāhir al-Zāwī al-Ṭarābulusī $(1890-1986)^{38}$ and Muhammad Mușțafá Bāzāma (1923-2000) ${ }^{39}$. In their works, the writing of a Libyan national history appears as a new element in historical scholarship, and the subject of history is therein redefined and renewed. However, in reality, this apparent innovation was merely a facade. Although these authors insisted on the periodization of the history of Libya, they carried out no critical analysis of the texts on which they drew ${ }^{40}$.

While some Arab studies have given Libya a place of only secondary importance in the North African conquest, other researchers have gone further by drawing direct links between the conquest and the history of certain important Libyan localities. The most obvious example is that of the city of Tripoli. As the historical capital of the eponymous province (Tripolitania) and the seat of Arab governors, the city has been the subject of numerous studies ${ }^{41}$ Other locations, such as Barqua ${ }^{42}$, Benghazi ${ }^{43}$, Sabratha ${ }^{44}$, Fazzan $^{45}$, and Germa ${ }^{46}$, have also been subjected to this new manner of treating the conquest primarily in terms of its long-term historical consequences. While this approach may be innovative, it nevertheless raises many problems. As the titles of these works indicate, they were inspired by places. As a result, even when they begin with a historical overview and contextualization of the place,

37. A. Mkacher, "La storiografia in arabo della conquista islamica della Libia", Quaderni di Archeologia della Libia, 23, 2020, 201-210.

38. We can note the beginning of his interest in Libyan history in 1930, when he edited Ibn Galbūn's text (d. in 1737): al-Ṭ.-A. al-Zāwī, Tārīh Ṭarābulus al-Garb al-musammá al-tadkār fīman malak Ṭarābulus wamā kāna buhā min al-ahbār, Cairo, 1930. But his most important works on the subject are Tärīh al-Fath al-'Arabi li Lībiyā, Cairo, 1954, 30-61; Mu'jam al-buldān al-Lībìyah, Tripoli, 1968 (esp. 23-26); and Wulāt Ṭarābulus min bidāyat al-fath al-'Arabī ilá nihāyat al-'ahd al-Turkī, Beyrouth, 1970 (esp. 9-33).

39. M.-M. Bāzāma, Tārīh Lībiyā. al-ğuz' al-țāmin. al-qism al-awwal, fī 'ahd al-h́ulafā̀ al-rāšidūn, Beyrouth, 1973, 73-177 (with an analysis and commentary of the texts, but without criticism). Following the same trajectory, we can also cite the works of 'A. al-Lațîf Maḥmūd Barghūthī, al-Tārīkh al-Lìbì al-qadìm, min aqdam al-'ușūr hattá al-fath al-Islāmī, Tripoli, 1971; 'Abd al-Lațîf Maḥmūd Barghūthī, Tārīkh Lìbiyā al-Islāmī, min al-fath al-Islāmī ḥattá bidāyat al-'așr al-'Uthmānī, Tripoli, 1973; and H.S. Mạ̣mūd, Lìbiyā bayna al-māḍ̄ wa-al-hädir, Cairo, 1962 (esp. 50-52), in Arabic.

40. 'A. Sa'd Zağlūl, Fatra ḥāsima min tārīh al-Mağrib, Bingazi, 1953; S.-M. Miftaḥ, Libiya: mundhu al-Fath al Arabi, Tripol, 1978, 23-59; M.-M. Grayou, Taragim al-Sahaba al-Machhourin, Tripoli, 1973, 10-37 (in Arabic).

41. R. Rasem, Tarābulus al-Garb bayn al-Madhi wa al-Hadhir, Tarabuls, 1953, 37-72 (esp. 60-72); N. Muhammad, Tarābulus al-ġarb, Tripoli, 1973, 125-132; N. al-Kit, Madinat Tarabuls, Tripoli, 1978, 45-50; K.-M. Tillisi, Hikayat Madinat, Tarabuls, Tripoli, 1985, 23-45 (in Arabic).

42. M. Ghannāy, 'A, Dirāsah ḥawla madīnat Barqah Bin-Ghāzī, Binḡāzī, 1975, 5-39 (in Arabic).

43. M.-M. Bāzāmah, Madīna Binġazì 'abra al al-Tarih, vol. 1, Binġāzī, 1968, 202-210.

44. M.-A. Isa, Madinat Sabratha munth al-istitane al-Finiqi hatha al-wagth al hathir, Tripoli, 1977, 89-90 (in Arabic).

45. M.-S. Ayyūb, Muhtasar tarīh Fazzan, Tripoli, 1967 (in Arabic).

46. M.-S. Ayyūb, Ǧarmah, Tripoli, 1969, 228-232 (in Arabic). 
the analysis is essentially centred on the geographical territory itself. These works rely, thus, on what we might call the "physiognomy" of the place rather than on the sources, which take on only a secondary role. In these studies, the narrative of the conquest is only a preamble to the study of the historical evolution of the place in question ${ }^{47}$.

\subsection{Tunisian Historians}

In Tunisia, Hassan Hosni Abdelwaheb (1884-1968) is considered to be one of the first historians to have focused on the period of the conquest. In 1914, Abdelwaheb published his Summary of the History of Tunisia (Hulāșat Ta'rīh Tünis) ${ }^{48}$, a work written primarily to serve as a school textbook aimed at helping Tunisian schoolchildren come to know "their history". He also authored a more detailed work entitled Waraqāt 'an al-hadāra al-'Arabiyya ${ }^{49}$. Drawing on his familiarity with and knowledge of medieval Arabic sources, Abdelwaheb continued his research by studying the city of Kairouan, which led him to criticize its founding myth $^{50}$.

After independence, the early centuries of Islam sparked the enthusiasm of a new generation of Tunisian historians, although none chose to dedicate a monograph to the subject. Two examples of such scholars are Hichem Djait (born in 1935) and Mohamed Talbi (19212017). In two major papers published in 1967 and 1968, Djaït painted a picture of North Africa both during and after the Arab conquest ${ }^{51}$. Talbi is the author of a fundamental work on the Aghlabids. In 1971, he published a remarkable analysis of Al-Kahina's epic, taking as his starting point a new fragment of the history of the Muslim West attributed to al-Raqiq, an attribution on which he cast doubt ${ }^{52}$.

The scholars of the Arab conquest discussed above were all Medievalists, but this monopoly was broken in the 1980s by Hédi Slim, an archaeologist specialized in antiquity.

47. 'M. Mannā, Al-Ṣaḥrā' al-lībiyya, Binġāzī, 1969.

48. H.-H. Abdelwaheb, Hulūạsat tārīh Tūnis, Tunis, 1953 (in Arabic).

49. H.-H. Abdelwaheb, Waraqāt 'an al-ḥad̄ara al-Arabiyya bi-Ifrīqiya al-Tūnisiyya, 3 vols., Tunis, 19651966 (in Arabic).

50. H.-H. Abdelwaheb, “Sur l'emplacement de Qairouan”, Revue Tunisienne, 1940, 51-53; H.-H. Abdelwaheb, "Villes arabes disparues", in Mélanges offerts à William Marçais par l'Institut d’études islamiques de l'Université de Paris, Paris, 1950, 1-15; H.-H. Abdelwaheb, "Les steppes tunisiennes (région de Gamouda) pendant le Moyen Âge", Cahiers de Tunisie, 2, 1954, 5-16.

51. H. Djaït, "La Wilâya d'Ifriqiya aux IIe et IIIe siècles: étude institutionnelle”, Studia Islamica, 27, 1967, 77-122; and 28, 1968, 79-107; H. Djaï, "L'Afrique arabe au VIIIe siècle (86-184/705-800)", Annales. Économie, Sociétés, Civilisations, 1973, 601-623.

52. M. Talbi, “Un nouveau fragment de l'histoire de l'Occident musulman (62-196; 682-812). L'épopée d'al-Kahina", Cahiers de Tunisie, 20, 1971, 19-52; M. Talbi, "Hassân ibn al-Nu'man”, E.I.', 3, 1971, $279 ;$ M. Talbi, “Al-Kâhina”, E.I. ${ }^{2}$, 5, 1982, 440-442; M. Talbi, "Kusayla”, E.I. ${ }^{2}$, 5, 1982, 521; M. Talbi, Études d’histoire ifriqiyenne et de civilisation musulmane, Tunis, 1982; M. Talbi, "Le christianisme maghrébin de la conquête musulmane à sa disparition. Une tentative d'explication”, in M. Gervers and R.J. Bikhazi (eds.), Conversion and Continuity. Indigenous Christian Communities in Islamic Lands, Eighth to Eighteenth Centuries, Toronto, 1990, 313-351. 
The publication of a Byzantine treasury discovery at Rougga (ancient Bararus), the burial of which seems to have been related to the first Arab raids against the Byzacene, provided this author with the opportunity to exploit Arab sources and thus to participate in the study of this pivotal phase in the history of the region ${ }^{53}$.

\subsection{Algerian Historians}

In Algeria, the political will of the nation in the aftermath of independence was articulated around a return to "Islamic" origins. As a result, Algerian historians tended to glorify the Arab conquerors while minimising episodes of Berber resistance to the various Arab expeditions, as is evident in Mubarak al-Mìlìss work on the history of Algeria and in that of Laqbāl Mūsa ${ }^{54}$.

However, as in Tunisia, a new generation of Algerian historians is now forging new paths in the study of Algerian history and the history of the Maghreb in general. Examples of scholars working in this tradition include Alaoua Amara ${ }^{55}$, Youssef Aibech ${ }^{56}$, Abderrahman Khalifa $^{57}$, and Bakhta Moukraenta ${ }^{58}$.

\subsection{Moroccan Historians}

The approach of Moroccan scholars to the study of history bears some significant similarities with that taken by historians in Libya. The work of Aḥmad al-Salāwi (1835-1897) ${ }^{59}$ can serve as an example. Al-Salāwī was content simply to collect Arab narratives related to the Muslim conquest of Morocco. The compilation of sources was also the goal of a work published in the sixties by 'Abd al-Salām al-Marrī' ${ }^{-0}$, while a book by Ibrāhīm Harakāt (1929-2020) follows a similar approach ${ }^{61}$. On the other hand, as in Libya, the collected Arab sources are subject

53. H. Slim, "Le trésor de Rougga et l'expédition musulmane de 46 en Ifriqiya”, in Mission archéologique franco-tunisienne de Rougga (1971-74), Rome, 1980, 75-96.

54. M.-M. al-Mīlī, Tārīhn Al-Ǧazā’ir fī al-qadīm wa-al-hadīt, Alger, 1963; M.-M. al-Mīlī, Tārīkh al-Maghrib al-Islāmì, Alger, 2001 (4th ed.); M.-M. al-Mìlī, 'Uqbah ibn Nāfi asās nizām al-Fihrīyìn, Alger, 2002 (in Arabic).

55. A. Amara, Maghrib-awsatiyyat, études sur l'histoire et la civilisation de l'Algérie au Moyen Âge islamique, Constantine, 2013.

56. Y. Aibech, L'occupation byzantine du Maghreb, étude de la vie sociale et économique, Constantine, 2009 (in Arabic).

57. A. Khalifa, "L’Aurès au moment de la conquête arabe", Aouras, 2006, 3, 207-227; A. Khalifa, "L’urbanisation dans l'Algérie médiévale", Antiquités Africaines, 40-41, 2004-2005, 269-287; A. Khalifa, "Masmuda", Encyclopédie Berbère, 30, 2010, 4644-4646.

58. B. Moukraenta, Les villes de l'Algérie antique: au travers des sources arabes du Moyen Âge, 2 vols., Saarbrücken, 2015.

59. A. al-Salāwī, Kitāb al-Istiqșā li-aḥbār duwal al-Maghreb al-Aqșā, Casablanca, 1894-1895 (in Arabic). The part of the book concerned with the conquest was translated into French in 1923 by A. Graulle.

60. 'A. al-Marrī, Dalī mu’arrih al-Maibg̀r al-Aqșá, Casablanca, 1960-1965 (in Arabic).

61. I. Harakāt, al-Mag̀rib ‘abra al-tārīh, Casablanca, 1965, vol. 1, 71-94. 
to almost no critical analysis at all. After the independence of Morocco, as also happened in Algeria, the teaching and study of early Islam came to be dominated by nationalist ideology. The work of the historian and Islamologist Abdallah Laroui (born in 1933) provides a striking example of this trend ${ }^{62}$. The section of this work that deals with the Arab conquest is found in the first part of the volume, entitled "The Maghreb dominated" (pp. 19-98), which covers the period from $2000 \mathrm{BCE}$ to the $8^{\text {th }}$ century CE. This phase is framed in terms of the "conquered autonomy" of the region, an autonomy that the author does not consider to have been broken by the Arab conquest on the grounds that the Berbers continued their fight against the foreign invaders. Laroui then goes on to consider the emergence of indigenous powers in the Maghreb in the Middle Ages as the crowning achievement of this long struggle for the country's independence and autonomy. Laroui is sharply critical of all "foreign" writings on the history of the Maghreb, a criticism that is undeniably rooted in his ideology.

A partial revision of this idea can be seen in the work of Mohamed Kably ${ }^{63}$, who, while trying to give a new interpretation of the subject matter, only reinforces the idea that the conquest was indeed an "invasion", the first victim of which was the "Berber people". Genuinely innovative scholarship on the topic of the conquest and the arrival of Islam came in the 1990s with the work of Ahmed Siraj. In his L'image de la Tingitane ${ }^{64}$ (1995), Siraj analysed the Arab narratives in depth, considering their content and showing how modern scholars can really exploit these texts when writing about this period.

\section{$3.21^{\text {st }}$ century Studies on the Conquest}

\subsection{Yves Modéran's Precursory Work}

One of the scholars who contributed the most towards demonstrating the importance of this period was the late Yves Modéran (1955-2020) ${ }^{65}$. An eminent expert on Late, Vandal, and Byzantine Africa ${ }^{66}$, Modéran's publications exhibit all the advantages to be gained from the

62. A. Laroui, L'histoire du Maghreb. Un essai de synthèse, Paris, 1970; A. Laroui, L’idéologie arabe contemporaine, Paris, 1967.

63. M. Kably, Histoire du Maroc. Réactualisation et synthèse, Rabat, 2011.

64. A. Siraj, L'image de la Tingitane. L'historiographie arabe médiévale et l'Antiquité nord-africaine, Rome, 1995.

65. On the work of Y. Modéran, see "Bibliographie d'Yves Modéran”, Antiquités Africaines, 45, 2009, 1821.

66. See Y. Modéran, “Corippe et l'occupation byzantine de l'Afrique: pour une nouvelle lecture de la Johannide”, Antiquités Africaines, 22, 1986, 195-212; Y. Modéran, "Koutzinas/Cusina. Recherches sur un Maure du VIe siècle", in A. Mastino, L’Africa romana. Atti del VII convegno di studio (Sassari, 15-17 dicembre 1989), Sassari, 1990, 393-407; Y. Modéran, “La découverte des Maures”, Cahiers de Tunisie, 43, 1991, 211 238; Y. Modéran, "Les frontières mouvantes du royaume vandal”, in Cl. Lepelley and X. Dupuis (eds.), Frontières et limites géographiques de l’Afrique du Nord antique. Hommage à Pierre Salama, Paris, 1999, 241-264; 
study of Arab sources. In addition to his major work on the Moors and the Roman Empire ${ }^{67}$, Modéran also authored studies on leaders of the Berber resistance, such as Kusayla ${ }^{68}$ and Kahina ${ }^{69}$. He is also the author of a strikingly original study in which the non-Arab sources are related to the history of Gregory the Patrician, a leading figure in Byzantine Africa ${ }^{70}$.

\subsection{The Confirmed Research Focus}

In this chapter, we have examined the contributions of national schools to the definitive emancipation of the period of the conquest from the tug-of-war between classicists and medievalists. As the study of the conquest has evolved, it has become a truly independent and richly renewed field of research, as can be seen in works ranging from the as-yet unpublished thesis of Mohamed Benabbès ${ }^{71}$ to the studies of Hichem Djait ${ }^{72}$, Ahmed el Bahi ${ }^{73}$, Hayet $\mathrm{Amamou}^{74}$, and the late Mohamed Tahar Mansouri ${ }^{75}$.

In the western sphere, and particularly in France, recent publications have shown definitively that there is a new impetus in the study of this period. Of particular note in this regard is the publication in 2011, under the direction of Dominique Valérian ${ }^{76}$, of a volume entitled L'Islamisation et l'arabisation de l'Occident musulman ( $\mathrm{VII}^{\mathrm{e}}-\mathrm{XII}{ }^{\mathrm{e}} \mathrm{s}$.), which collects together important papers from the seminar "Medieval Islam of the West", organized between 2006 and 2007. The full historical potential of the study of the Maghreb can be seen in the contri-

Y. Modéran, "Les Vandales et la chute de Carthage", in Cl. Briand-Ponsart and S. Crogiez (eds.), L'Afrique du Nord antique et médiévale: Mémoire, identité et imaginaire, Rouen, 2002, p. 97-132.

67. Y. Modéran, L'Empire romain tardif (235-395 ap. J.-C.), Paris 2003.

68. Y. Modéran, "Koceila (Kusayla, Kasîla)", Encyclopédie Berbère, 28-29, 2007, 4255-4264; Y. Modéran, "Kusayla, l'Afrique et les Arabes", in Cl. Briand-Ponsart (ed.), Identités et cultures dans l'Algérie antique. Actes du colloque international (Rouen, mai 2003), Rouen, 2005, 423-457; Y. Modéran, "Botr et Branès. Sur les origines du dualisme berbère medieval", in H. Bresc and C. Veauvy (eds.), Mutations d'identités en Méditerranée, Paris, 2000, 53-66.

69. Y. Modéran, "Kahena", Encyclopédie Berbère, 27, 2005, 4102-4111.

70. Y. Modéran, "Le dossier des sources non musulmanes sur l'exarque Grégoire et l'expédition arabe en Ifrîkiyya en 647-648”, in L.A. García Moreno and M.J. Viguera Molins (eds.), Del Nilo al Ebro. Estudios sobre las fuentes de la conquista islámica, Alcalá de Henares, 2010, 141-180.

71. M. Benabbès, L'Afrique byzantine face à la conquête arabe. Recherche sur le VII siècle en Afrique du Nord, PhD thesis, University of Nanterre, 2004.

72. H. Djait, La fondation du Maghreb islamique, Sfax, 2004.

73. A. El Bahi, Sousse et le Sahel à l'époque médiévale: essai de géographie historique, Tunis, 2004.

74. H. Amamou, Aslamat Bilad al-Maghrib. Islam at-ta'sis, mina-l- futuhat 'iladhuhur al-nihal, Tunis, 2004.

75. M.-T. Mansouri, La Tunisie au Moyen Age. L'Ifriqiya de la province dépendante a l'autonomie, Tunis, 2006.

76. D. Valérian (ed.), L'Islamisation et l'arabisation de l'Occident musulman (VIIe-XIIe s.), Paris, 2011. 
butions of Cyrille Aillet ${ }^{77}$, Christophe Picard ${ }^{78}$, Alaoua Amara ${ }^{79}$, Anleese $\mathrm{Nef}^{80}$, Dominique Valérian $^{81}$, and Yassir Benhima. A similar validation of the new approach can be found in the Anglo-Saxon works of Hugh Kennedy ${ }^{82}$ and Fred Donner ${ }^{83}$, and in Walter E. Kaegi's Muslim Expansion and Byzantine Collapse in North Africa ${ }^{84}$.

We conclude this historiographical overview with a collection of accounts of the Arab conquest of the Maghreb that has just been published ${ }^{85}$, offering for the first time an anthology of the narrative texts concerned with the beginning of Islam in North Africa. It is hoped that this work will encourage further research on the issue.

77. D. Valérian (ed.), L'Islamisation et l'arabisation..., op. cit., n. 76, 7-34.

78. D. Valérian (ed.), L'Islamisation et l'arabisation..., op. cit., n. 76, 35-61.

79. D. Valérian (ed.), L'Islamisation et l'arabisation..., op. cit., n. 76, 103-130.

80. D. Valérian (ed.), L'Islamisation et l'arabisation..., op. cit., n. 76, 63-99.

81. D. Valérian (ed.), L'Islamisation et l'arabisation..., op. cit., n. 76, 131-149.

82. H. Kennedy, The Great Arab Conquests, Philadelphia, 2007.

83. F. Donner, The Expansion of the Early Islamic State, Aldershot, 2008.

84. W.E. Kaegi, Muslim Expansion and Byzantine Collapse in North Africa, Cambridge, New York and Melbourne, 2010. The responses and criticisms formulated in particular in the report by C. Morrison and V. Prigent in The Medieval Review, 2013, led the author to revise some of his conclusions in his later work, "The Islamic Conquest and the Defense of Byzantine Africa. Reconsiderations on Campaigns, Conquests, and Contexts", in S.T. Stevens (ed.), North Africa under Byzantium and Early Islam, Washington D.C., 2016, 65-87. In the same book, we can also mention the work of M. Benabbès, "The Contribution of Medieval Arabic Sources to the Historical Geography of Byzantine Africa”, 119-128.

85. A. Mkacher and M. Benabbès, La conquête arabe de l'Afrique romaine. Anthologie de textes arabes, Paris, 2020. 